IDENTIFICATION WITH EUROPE, INTEGRATION POLICIES, AND PREJUDICE

Inclusive normative climates strengthen the relationship between identification with Europe and tolerant immigration attitudes: Evidence from 22 countries

Emilio Paolo Visintin, Eva G. T. Green, Oriane Sarrasin

Institute of Psychology, University of Lausanne

Corresponding author: Emilio Paolo Visintin, Bâtiment Géopolis, 1015 Lausanne emiliop.visintin@gmail.com

Acknowledgement: This work was supported by a Swiss National Science Foundation grant awarded to Eva G. T. Green and Juan Manuel Falomir-Pichastor (100014_159336 / 1).

Manuscript in press in Journal of Cross-Cultural Psychology. Special issue of JCCP “Europe's culture(s): Negotiating cultural meanings, values, and identities in the European context”. 
IDENTIFICATION WITH EUROPE, INTEGRATION POLICIES, AND PREJUDICE

\begin{abstract}
Europe as a supranational entity is frequently associated to inclusive and cosmopolitan values, which explains why identification with Europe generally relates to tolerant attitudes toward immigrants. However, because of major immigration movements, Europe has recently gone through demographic and social changes that have challenged its values and identity. In this context, we argue that, because national immigrant integration policies convey social norms about how citizens should deal with issues related to immigration, policies should also shape the association between identification with Europe and attitudes toward immigrants. Indeed, tolerant, more so than intolerant, policies in a country lay the foundations for interpreting identification with Europe as an inclusive stance, and consequently should enhance the association between identification with Europe and reduced anti-immigrant attitudes. To investigate these associations, we conducted a cross-country multilevel analysis including 22 European countries from the 2013 International Social Survey Programme. As predicted, identification with Europe was associated to reduced anti-immigrant prejudice. Furthermore, this negative association was stronger in countries with more tolerant, inclusive policies (assessed by the MIPEX) compared to countries with more intolerant, exclusive policies. Results are discussed in light of the content of European identity and of different embodiments of social norms.
\end{abstract}


IDENTIFICATION WITH EUROPE, INTEGRATION POLICIES, AND PREJUDICE

\title{
Inclusive normative climates strengthen the relationship between identification with Europe and tolerant immigration attitudes: Evidence from 22 countries
}

\begin{abstract}
So we are the good Europeans, and we defend Europe, not just at the levels of values, but at the levels of reality when we defend Schengen borders, as it is written in the Schengen treaty.

Viktor Orbàn, Prime Minister of Hungary
\end{abstract}

We have the duty to restore the values on which Europe was founded. The Geneva Convention was signed by all of us, and the right of asylum is granted by the article 10 of our [Italian] Constitution. It is a legal and moral obligation that cannot be ignored by any democratic state. Laura Boldrini, President of the Chamber of Deputies of Italy

Mass-immigration from African, Asian, and Middle-Eastern countries to Europe has increased dramatically in the last decades. Migration movements within Europe have also intensified, partly due to the freedom of movement between countries belonging to the Schengen area. Both phenomena have elicited resistance and negative reactions. These major demographic and social changes have indeed been accompanied with a rise of radical right and populist parties, which call for the reestablishment of strict borders. From a social psychological point of view, these consequences both stem from and feed heightened identification with the nation and threat perceptions associated to immigration. Among citizens of European countries, however, identifying with the European continent — an entity that transcends national borders - has been generally shown to relate to positive immigration attitudes (for a review, see Datler, 2016). Yet it remains unknown whether this relationship varies across countries. Indeed, as the two quotes above reveal, the values associated to 
Europe - openness vs. desire to restrict access—-diverge greatly in political discourse. We suggest the normative context in which individuals are embedded - conveyed by the national integration policies - defines the nature associated to Europe.

The chief contribution of the current paper to social and cross-cultural psychology is examining whether national immigrant integration policies, as a manifestation of normative contexts in which individuals are embedded, define the nature associated to Europe and thus shape the relationship between European identification and immigration attitudes. Studying the role of European identification in forming immigration attitudes is particularly timely as the future of a shared Europe has been called into question. For example, the "leave" campaigning prior to the Brexit referendum of UK heavily drew on supposed threats immigration posed for UK. The current study is theoretically important because the focus of social psychological research has been on uncovering how the country-level normative context moderates the national identification-immigration attitudes link. Previous research has indeed shown that the impact of national identification - known to relate to prejudice against immigrants - is heightened in exclusive and intolerant climates (e.g., Ariely, 2012; Pehrson, Vignoles, \& Brown, \& 2009). Building on this body of research, we argue that the relationship between identification with Europe and immigration attitudes varies across European countries as a function of immigration related norms. These norms are reflected in the formal arrangements (i.e., policies) between the nation and its immigrant residents. We hypothesized that the negative relationship between identification with Europe and antiimmigrant prejudice should be stronger in countries with more inclusive integration policies. To test this prediction, we conducted a multilevel analysis on data from the 22 European countries participating to the 2013 International Social Survey Programme (ISSP).

\section{Identification with Europe and anti-immigrant prejudice}


IDENTIFICATION WITH EUROPE, INTEGRATION POLICIES, AND PREJUDICE

To begin with, the notion of European identification deserves some thought.

Identification with Europe refers to individuals' attachment to a continent that contains both European Union (EU) and non-EU member countries. Although the EU and Europe are obviously related, identification with Europe is distinct from identification with the European Union, which has been the focus of much political science research (e.g., Hobolt \& de Vries, 2016). Over and above geographical, proximity reasons, due to cultural, historical, political, or economic interconnectedness between European nations, individuals from any part of the European continent can feel European and attached to Europe. Indeed, also non EU-member countries from the European continent have political and economic agreements with EU members. For example, Iceland, Norway, and Switzerland adhere to the Schengen Agreement, which guarantees the free movement of people. Other countries like Turkey adhere to the European Union Customs Union as non-EU members. From a social psychological perspective, Europe can be considered a group with a real existence (Campbell, 1958) — an entity_-because people from different European countries share, at least partly, a common fate, similarities, proximity, and boundaries (see Castano, 2004; Castano, Yzerbyt, \& Bourguignon, 2003, for a discussion on entitativity of the EU).

Social identity theory (SIT; Tajfel \& Turner, 1979) asserts that being attached to and favoring the group one belongs to - the ingroup - covaries with rejection of outgroups. This assumption has led to extensive studies on the relationship between national identification and negative reactions against immigrant and ethnic outgroups (e.g., De Figuereido \& Elkins, 2003; Verkuyten, 2009). Although mere identification with the nation can be sufficient to trigger rejection of immigrant outgroups, this covariation is most prominent when national identification is uncritical and based on comparisons with other nations (Wagner, Becker, Christ, Pettigrew, \& Schmidt, 2012). Constructive and critical forms of national identification, in turn, tend to relate to more open immigration attitudes (Blank \& Schmidt, 2003; 
Mummendey, Klink, \& Brown, 2001). This suggests that the norms associated to the content of group identity determine whether identification with such a group relates to outgroup rejection or not (see Reicher \& Hopkins, 2001).

Unlike national identification, feelings of belonging to Europe transcend national borders (Curtis, 2014). Moreover, a European identity is generally associated to tolerance (Licata \& Klein, 2002), to egalitarianism (McCormick, 2010), and to cosmopolitanism (Schlenker, 2013). This inclusive content of European identity suggests that the classic ingroup favoritism-outgroup rejection SIT prediction does not apply to the case of identification with Europe. Unlike national identification, identification with Europe should relate to lower levels of prejudice against immigrants, both those coming from other European "subgroups" (e.g., other countries from the European continent) and from outside Europe. Supporting this assumption, across 27 European countries, European identification was found to relate negatively to hostility toward immigrants (Curtis, 2014; see also Citrin \& Sides, 2004). In a Belgian study among adolescents, Quintelier and Dejaeghere (2008) found a positive association between identification with Europe and tolerance toward immigrants and ethnic minorities (see however Licata \& Klein, 2002). Similar links between identification with Europe and reduced prejudice towards immigrants have been found in various German samples (e.g., Strobaneck, 2004).

The bulk of evidence thus clearly points toward a positive relationship between identification with Europe and tolerant attitudes towards immigrants, and we expected a similar covariation in the present study $(\mathrm{H} 1)$. Whether this relationship is prone to crossnational variation, however, has remained unstudied until now. As outlined in the next section, we suggest that this relationship is stronger in countries characterized by tolerant policies and practices toward immigrants and cultural diversity.

Immigration policies, identification with Europe, and anti-immigrant prejudice 
IDENTIFICATION WITH EUROPE, INTEGRATION POLICIES, AND PREJUDICE

Research has amply established that egalitarian and tolerant social norms - such as when perceiving or being told that fellow ingroup members hold progressive attitudes toward outgroups - have the power to mitigate and deter the expression of prejudice (e.g., Crandall Eshleman, \& O'Brien, 2002; Falomir-Pichastor, Muñoz-Rojas, Invernizzi, \& Mugny, 2004). Policies constitute concrete institutional characteristics of the social environment and, in that respect, prescribe attitudes and behaviors (see Morris, Hong, Chiu, \& Liu, 2015; also Chiu et al., 2015; Staerklé, 2009) thereby enacting social norms (see Andreouli \& Howarth, 2013). Immigration and integration policies define the boundaries between the national ingroup and immigrant outgroups, for example by determining access to the political sphere or labor market. Thus, they convey the level of tolerance toward immigrants expected by the authorities (Green \& Staerklé 2013; Kauff, Asbrock, Thörner, \& Wagner, 2013). The sense of national policies is transmitted through multiple sources, via the educational system (see Coenders \& Scheepers, 2003; Hjerm, 2001), the work place (e.g., through organizational diversity policies), the media as well as political and legal instances.

There is evidence that integration policies affect how individuals perceive their fellow citizens' opinions about immigration and diversity. Guimond et al. (2013) found across four countries that perceived norms (e.g., observing that national group members support helping minorities keep their cultural heritage) differed consistently as a function of actual national policies (e.g., prevalence of multiculturalist policies). Norms are thus embodied in national integration policies. Analyzing data from two social surveys comparing European countries, Schlueter, Meuleman, and Davidov (2013) demonstrated that national majority members' perceptions of threat posed by immigrants were lower in countries characterized by tolerant, inclusive integration policies than in countries characterized by intolerant policies (for similar results see Callens \& Meuleman, 2016; Hooge \& de Vroome, 2015; Weldon, 2006). Likewise, Ariely (2012) and Wright (2011) showed that countries with more inclusive 
IDENTIFICATION WITH EUROPE, INTEGRATION POLICIES, AND PREJUDICE

citizenship legislations hosted more inclusive and tolerant attitudes toward immigrant minorities. Based on this evidence, we-expected that tolerant immigrant integration policies relate to reduced prejudice toward immigrants $(\mathrm{H} 2)$.

In addition to directly impacting citizens' attitudes toward immigrants, country-level policies should also shape the relationship between European identification and prejudice. When identifying with Europe, people are more likely to have in mind values such as openness and tolerance if they perceive the climate — enacted by national policies — as welcoming to and facilitating the integration of immigrants. Based on this reasoning, an inclusive normative climate should lay the foundation for interpreting identification with Europe as an inclusive stance, and therefore heighten the negative relationship between identification with Europe and anti-immigrant prejudice. While this has not until now been tested in the case of European identification, there is evidence that the positive relationship between national identification and anti-immigrant prejudice is attenuated in countries characterized by tolerant and inclusive norms.

Pehrson and colleagues (2009), for instance, reasoned that national identification affects attitudes toward immigrants differently according to the prevailing conception of the national ingroup (i.e., who is a "true" member). In line with their expectations, national identification was more strongly related to anti-immigrant prejudice in countries with an exclusive conception of nationhood (i.e., when importance was given to markers of cultural belonging to the nation, such as the requirement to speak the language of the country). The relationship was weaker in countries where people had a more inclusive conception of nationhood (i.e., when importance was given to civic criteria for national membership, such as possessing citizenship of the country). In a similar vein, the association between national identification and prejudice toward immigrants was found to vary as a function of national citizenship legislation (Ariely, 2012). National identification and anti-immigrant prejudice 
IDENTIFICATION WITH EUROPE, INTEGRATION POLICIES, AND PREJUDICE

were more strongly related in countries implementing "jus sanguinis" policies (where national ancestry facilitates access to citizenship) compared to countries characterized by more inclusive, "jus solis" or birthright, citizenship policies. Extending this reasoning, we expected the association between European identification and reduced prejudice towards immigrants to be enhanced in countries with tolerant immigrant integration policies, that is, in inclusive normative climates supporting immigrants $(\mathrm{H} 3)$.

\section{Method}

\section{Sample}

We relied on data from the 22 European countries (18 EU members and 4 non-EU members, see Table 1) that participated in the 2013 ISSP survey. The questionnaire was administered in local languages. We considered only respondents with the citizenship of the country where data were collected $(N=27,170)$. Mean age was $48.50(S D=17.34)$, and $53.4 \%$ of respondents were female. Mean of years of education was $12.58(S D=4.03) .{ }^{1}$ These data were then supplemented with national-level indicators. ${ }^{2}$

\section{Individual-level variables}

Five items were used to assess the dependent variable, anti-immigrant prejudice. Participants had to provide their agreement — on a scale ranging from 1 (agree strongly) to 5 (disagree strongly) — with the following sentences: "Immigrants increase crime rates" (reverse coded), "Immigrants are generally good for [country’s] economy”, “Immigrants take jobs away from people who were born in [country]" (reverse coded), "Immigrants improve [country's nationality] society by bringing new ideas and cultures," and "[country's] culture is generally undermined by immigrants" (reverse coded). Principal-component analyses revealed that in all countries the five items loaded on one anti-immigrant prejudice factor (note that a few loadings were slightly lower in Turkey, but never inferior to .27). Overall Cronbach's alpha for the five items was .80 (alphas by country ranged from .64 to .88). The 
IDENTIFICATION WITH EUROPE, INTEGRATION POLICIES, AND PREJUDICE

five items were averaged to create a composite score with higher values reflecting higher antiimmigrant prejudice. This score was linearly rescaled from 0 to 100 , to obtain the precise covariance estimates necessary to plot interaction effects.

Identification with Europe was assessed with the following question: "How close do you feel to Europe?". The response scale ranged from 1 (very close) to 4 (not close at all). The scale was reversed so that higher values represent a higher identification.

The degree to which respondents identify with the nation was also accounted for, both to ensure that we do not measure a general tendency of attachment to ingroups and to test for interactions between the two forms of identification. Indeed, the negative association between inclusive European identification and prejudice might be reduced by high levels of an exclusive national identification. National identification was assessed with an item similar to identification with Europe, with Europe being replaced with the name of the country of data collection, and the same reverse-coded scale. Identification with Europe and national identification were moderately related, $r(27,168)=.35, p<.001$.

We controlled for gender and age, because men and older individuals tend to reject immigration to a greater extent than women and younger individuals (Ceobanu \& Escandell, 2010). Years of education was also controlled for, because previous research has shown that longer education predicts reduced prejudice (Lancee \& Sarrasin, 2015) and higher identification with Europe (Hadler, Tsutsui, \& Chin, 2012).

Missing values on individual-level variables (i.e., on socio-demographic variables and on items measuring anti-immigrant prejudice, identification with Europe, and national identification) ranged between $0.1 \%$ (on gender) and $5.9 \%$ (on the second item assessing prejudice). They were imputed using the Expectation Maximization algorithm (Scheffer, 2002). ${ }^{3}$

\section{Country-level variables}


IDENTIFICATION WITH EUROPE, INTEGRATION POLICIES, AND PREJUDICE

To assess immigrant integration policies, we used the 2014 Migrant Integration Policy Index (MIPEX; Huddleston, Bilgili, Joki, \& Vankova, 2015). Ranging from 0 (exclusive) to 100 (inclusive), the MIPEX is a country-level indicator of immigrant integration policies that simultaneously considers several policy domains (i.e., equal access of immigrants to healthcare, education, political participation, and labor market, anti-discrimination laws, security of permanent residence and access to nationality, and policies favoring family reunions). Table 1 shows that the indices of countries included in the present analysis ranged from 24 (Turkey) to 80 (Portugal and Sweden; $M=53.27, S D=14.68$ ).

We also considered country-level characteristics that are known to explain national differences in anti-immigrant prejudice. Because cross-national studies have often found positive associations between immigrant ratio and prejudice (e.g., Scheepers, Gijsberts, \& Coenders, 2002), we accounted for the percentage of immigrants in $2015(M=11.40, S D=$ 5.94, range: 3.27 - 29.39; United Nations, 2016). Anti-immigrant prejudice has been found to be higher in countries characterized by economic deprivation (e.g., Gorodzeisky, 2011). Therefore we controlled for the country-level percentage of unemployment $(M=8.91, S D=$ 4.73, range: 3.30 - 22.50; Central Intelligence Agency, 2016) and for the GINI index, which measures inequality in the distribution of income $(M=30.02, S D=4.60$, range: $23.70-40.20$; Central Intelligence Agency, 2016).

In addition, we considered characteristics particularly relevant in cross-European comparisons on identification and prejudice. First, because anti-immigrant prejudice is generally higher in East European, post-socialist countries than in West European countries that did not experience a socialist regime (e.g., Strabac \& Listhaug, 2008), we controlled whether countries had a post-socialist background vs. not. Post-socialist countries (i.e., Croatia, Czech Republic, Estonia, Hungary, Latvia, Lithuania, Slovakia, and Slovenia) were coded -1 , while the remaining non-post-socialist countries were coded $+1 .{ }^{4}$ Second, we 
IDENTIFICATION WITH EUROPE, INTEGRATION POLICIES, AND PREJUDICE

controlled for EU membership, because identification with Europe might have different meanings for individuals from EU and from non-EU countries. Non-EU members (Iceland, Norway, Switzerland, and Turkey) were coded -1 , while EU members were coded +1 . There were no missing values for the country-level variables. Since we estimated interaction terms, the MIPEX and the GINI index, as well as percentages of immigrants and of unemployment were grand-mean centered. The correlations between MIPEX and the country-level controls were moderate (highest correlation $r(20)=-.56, p=.007$ ).

\section{Results}

Anti-immigrant prejudice varied significantly between countries $\left(\mathrm{ICC}=.097 ; \sigma^{2}=\right.$ $41.41, S E=12.79, p=.001)$, confirming the suitability and relevance of models that allow testing the impact of both individual- and contextual-level predictors (multilevel modeling; Hox, 2010). We thus performed multilevel regression analysis with Mplus 5.1 using maximum likelihood estimations. Anti-immigrant prejudice was regressed upon identification with Europe and individual-level control variables (i.e., gender, age, education, and national identification) as well as the MIPEX index. Variables were included step by step to the model and improvement of the explanatory power of the model was assessed by calculating differences in deviance $(-2 \times \log$ likelihood; see bottom panel of Table 2$)$. Compared to the baseline model (Model 0, intercept only), the model fit improved when individual-level predictors were included (Model 1), $\Delta \chi^{2}(5)=2,583.63, p<.001$. The model fit further improved when MIPEX was entered in the model (Model 2), $\Delta \chi^{2}(1)=4.98, p=.026$. In Model 3a, the slope between identification with Europe and prejudice was allowed to vary across countries (note that identification with Europe was centered at the group mean; Enders \& Tofighi, 2007). Allowing the slope between identification with Europe and prejudice to vary improved the model fit, $\Delta \chi^{2}(1)=256.66, p<.001$. Finally, the model fit was further 
IDENTIFICATION WITH EUROPE, INTEGRATION POLICIES, AND PREJUDICE

improved when MIPEX was modeled as a predictor of the slope between identification with Europe and prejudice (Model 3b), $\Delta \chi^{2}(1)=7.60, p=.006$.

The associations between variables were examined next (see top panel of Table 2). Supporting H1, identification with Europe was related to lower prejudice toward immigrants (Model 1). By way of contrast and confirming previous research on the topic, national identification was positively associated with anti-immigrant prejudice. In addition, men and older people reported more prejudice, while respondents with a higher education level expressed lower prejudice. Confirming H2, lower prejudice towards immigrants was expressed in countries with more tolerant and inclusive integration policies (i.e., higher MIPEX; Model 2). Furthermore, the MIPEX significantly moderated the relationship between identification with Europe and anti-immigrant prejudice (Model 3b). It is noteworthy that the MIPEX explained 32\% of the variance of the slope between identification with Europe and prejudice. In line with $\mathrm{H} 3$, the negative association between identification with Europe and prejudice was stronger in countries with high $\operatorname{MIPEX}(+1 S D, b=-4.44, S E=0.61, p<.001)$ than in countries with low $\operatorname{MIPEX}(-1 S D, b=-1.82, S E=0.61, p=.003$ : see Figure 1$)$.

\section{Additional analyses}

Additional analyses including country-level control variables were conducted to ensure that our findings were robust (see Table 3): We accounted for percentage of immigrants, unemployment rate, GINI index, being a post-socialist nation and being an EU member. Country-level control characteristics were added one by one as predictors of both anti-immigrant prejudice and the slope between identification with Europe and anti-immigrant prejudice (Models 3c to 3g, Table 3) (see Aguinis, Gottfredson, \& Culpepper, 2013). Antiimmigrant prejudice was lower in countries with higher ratio of immigrants, in countries without a socialist past, and in non-EU member countries. The negative association between MIPEX and prejudice remained significant in four out of five cases (this main effect was not 
significant, $p=.17$, when controlling for socialist past). Regarding cross-level interactions, none of the country-level characteristics under consideration significantly predicted the variation between identification with Europe and prejudice. Importantly, the hypothesized cross-level interaction remained: MIPEX always significantly predicted the relationship between identification with Europe and prejudice, albeit the effect was only marginally significant when controlling for socialist past $(p=.07) .^{5}$

Another set of additional analyses concerned national identification. First, exclusive national identification might attenuate the prejudice-reducing effect of inclusive European identification. We thus tested whether identification with Europe and national identification interacted in shaping anti-immigrant prejudice. Starting from Model 1, we included the interaction between identification with Europe and national identification (in this additional analysis the two predictors were mean centered). The interaction yielded a significant effect $(b=1.07, S E=0.16, p<.001)$. Decomposition of the interaction showed that the negative association between identification with Europe and anti-immigrant prejudice was stronger for respondents with lower national identification $(-1 S D, b=-4.12, S E=0.20, p<.001)$ compared to respondents with higher national identification $(+1 S D, b=-2.57, S E=0.17, p<$ $.001)$. Note that all the other results remained unaltered when running the main analysis controlling for the interaction between identification with Europe and national identification.

Second, given that immigrant integration policies may shape the content and the associations with prejudice of any form of identification, we tested whether the association between national identification and anti-immigrant prejudice varied between countries as a function of MIPEX. Starting from Model 2, we first allowed the slope between national identification and prejudice to vary, and found that the slope varied between countries $\left(\sigma^{2}=\right.$ 3.00, $S E=1.07, p=.005)$. Next, we added the MIPEX as predictor of the national identification-prejudice slope, and found that the cross-level interaction was marginally 
IDENTIFICATION WITH EUROPE, INTEGRATION POLICIES, AND PREJUDICE

significant $(b=-0.05, S E=0.03, p=.057)$. In line with Ariely (2012), the positive association between national identification and prejudice was stronger in more exclusive $(-1 S D, b=3.15$, $S E=0.54, p<.001)$ than in inclusive countries $(+1 S D, b=1.68 S E=0.54, p=.002){ }^{6}$

\section{Discussion}

This study contributed to the body of research on the relationship between identification with Europe and attitudes towards immigrants. Analyses with data from 22 countries showed that identification with Europe was related to lower levels of prejudice against immigrants, and positive attitudes were more prevalent in countries with inclusive immigration and integration policies. Importantly, we demonstrated that the relationship between identification with Europe and positive attitudes toward immigration was stronger in countries with inclusive rather than exclusive policies. While inclusive normative climates or policies are known to diminish the prejudice-fuelling impact of national identification, our findings provide a novel contribution to the literature on immigration attitudes by demonstrating that immigration and integration policies have the power to shape how identification with Europe — an identity transcending national borders — relates to such attitudes. This suggests that policies translate into social norms, which, in turn, influence the perceived values attached to Europe. This is highly relevant in an era where Europe as a political institution (the EU) is being questioned and the boundaries of Europe are constantly negotiated, for example via strengthened border controls as a response to the refugee crisis. In the following we further discuss the implications and the limits of this research.

\section{Europe as an inclusive identity}

First of all, it is noteworthy that at least some degree of identification with Europe was found in all countries under examination, comprised of both EU and non-EU members (including Turkey, which is a transcontinental country; see also Kennedy, 2013; Schilde, 2013, for identification with the EU among respondents from non-EU countries). This 
IDENTIFICATION WITH EUROPE, INTEGRATION POLICIES, AND PREJUDICE

confirms that Europe is a salient entity throughout the countries on the European continent.

Moreover, as in previous studies (e.g., Curtis, 2014; Kennedy, 2013; Quintelier \& Dejaeghere, 2008), identification with Europe was related to lower anti-immigrant prejudice.

The covariation between identification with Europe and reduced prejudice is likely due to the liberal and egalitarian values generally associated to Europe (see McKormik, 2010). However, as ISSP survey respondents were only asked to quantify their attachment to Europe, we can only speculate on the content of such identification (see Brewer, 2001; Licata, Sanchez-Mazas, \& Green, 2011). A minority of strongly identified individuals may associate Europe to other values or characteristics, and, for this reason, may express less positive attitudes toward immigrants. For instance, Licata and Klein (2002) found that Belgian undergraduates generally associate Europe to egalitarian and tolerant values. However, those who highly identified to Europe also saw it in terms of economy and citizenship, which may explain the positive relationship the authors found between European identification and antiimmigrant prejudice. Datler (2016) further found that the relationship between identification with Europe and tolerant attitudes toward foreigners was stronger for people who associated the European Union to social democracy, openness, and freedom but not to negative consequences such as economic burdens and increase of criminality (see also Sanchez-Mazas, van Humskerken, \& Gély, 2005). For these reasons, future studies on the topic should go, when possible, beyond a mere quantification of identification with Europe.

In addition, one could argue that while respondents from non-EU-member countries likely thought about the European continent when answering to the question, respondents from EU-member countries might have had either the European continent or the EU in mind. Even so, this should not hamper the conclusions drawn from the present study, because the results pattern held both when analyzing only the data from EU-member countries and when controlling for EU membership. 
IDENTIFICATION WITH EUROPE, INTEGRATION POLICIES, AND PREJUDICE

Finally, we must acknowledge that our findings reflect the associations between identification with Europe and anti-immigrant prejudice in 2013, the time of data collection. Current and future political and social changes in Europe might affect attachment to Europe and the inclusiveness of European identity. Political events such as the impending Brexit may have hampered the sense of attachment to Europe. Because refugees are often pictured as a threat, the current crisis and the resulting increase in border controls might also weaken the relationship between identification with Europe and reduced prejudice. The content and values associated to identities thus change over time. Future research should monitor the evolution of the content of identification with Europe and its associations with prejudice over time and as a function of political and social changes.

\section{The impact of immigrant integration policies}

In support of our key prediction, the association between identification with Europe and reduced anti-immigrant prejudice was found to be stronger in countries characterized by tolerant and inclusive immigration and integration policies. Thus, the lowest level of antiimmigrant prejudice appeared in conjunction with identification with Europe and tolerant group norms. Note however that identification with Europe was also related to reduced prejudice in less tolerant countries, albeit less strongly. This suggests that very likely in such countries the content associated to Europe is more controversial, which remains to be examined. These results concur with the assumption that policies convey norms about immigration (see also Guimond et al., 2013; Kauff et al., 2012; Schlueter et al., 2013) and for this reason provide the basis for interpreting identification with Europe as a more or less inclusive stance. As identification with Europe implies tolerant values, it is plausible that tolerant policies, rather than transforming the content of European identity, reinforce the consistency between the inclusive content of European identity and the expression of tolerant attitudes toward immigrants. Importantly, the present study revealed that country-level 
IDENTIFICATION WITH EUROPE, INTEGRATION POLICIES, AND PREJUDICE

policies do not only affect interpretation of the closely matching category (the nation and national identification) but also of a related but more distant category (Europe and identification with Europe). This highlights the powerful impact of social norms in attenuating or intensifying identity processes.

More generally, the present research shed light on how immigrant integration policies are received by national majority members (here citizens of European countries). Our results add to the body of research based on cross-national surveys revealing that in countries with tolerant policies, majorities perceive less threat and report lower anti-immigrant prejudice (Callens \& Meuleman, 2016; Hooge \& Vroome, 2015; Schlueter et al., 2013). Experimental research has also shown that exposure to multicultural policies can reduce ethnic prejudice (Wolsko, Park, Judd, \& Wittenbrink, 2000). Nevertheless, other experiments have found that exposure to multicultural ideologies can trigger prejudice (Morrison, Plaut, \& Ybarra, 2010), suggesting that multicultural policies can lead national majority members to perceive that their interests are undermined at the benefit of minorities and therefore to defy the norms conveyed by policies. Future research should thus examine these potential boundary conditions of the normative influence of integration policies.

\section{Presence of immigrants suggests intergroup contact}

Contrary to other cross-national studies on anti-immigrant prejudice (e.g., Scheepers et al., 2002; Weber, 2015), the present study revealed less prejudice towards immigrants in countries with higher ratios of immigrants. This prejudice-attenuating effect of immigrant presence has been more frequently found in studies comparing small geographical units (e.g., neighborhoods, regions; Wagner, Christ, Pettigrew, Stellmacher, \&Wolf, 2006). Indeed, diversity in small geographical and demographical units provides opportunities for intergroup contact, one of the main precursors of reduced prejudice (Pettigrew \& Tropp, 2011). At a 
IDENTIFICATION WITH EUROPE, INTEGRATION POLICIES, AND PREJUDICE

larger scale (e. g., on the level of countries), instead, the presence of immigrants might be politicized and mediatized, and consequently elicit threat (see Wagner et al., 2006).

We explain the seemingly contradictory result found in our study by the existence of intergroup contact and exposure to cultural diversity in countries with higher proportions of immigrants. Indeed, immigrant ratios in the countries under study differ dramatically, so that opportunities for intergroup contact (personal contacts, casual everyday interactions, extended contacts; see Pettigrew \& Tropp, 2011) clearly differ between countries. Temporality might have also played a role in favoring contact effects. When there is a long history of

cohabitation between nationals and immigrants, members of different communities have had time to develop interpersonal contacts, while more recent cohabitation is likely to elicit threat (see Pettigrew, 1998). Immigration histories of European countries differ starkly, with several of the high immigrant ratio countries having been destinations of immigration for decades (e.g., Switzerland, Germany, Sweden). While an in-depth analysis of determinants of the negative association between countries' immigrant ratios and anti-immigrant prejudice goes beyond the scopes of this article, we encourage future research to further explore this association and to examine the roles of intergroup contact and of temporality.

\section{Limitations and future directions}

We acknowledge some limitations of our study. First, data were correlational and we cannot infer causality. It is possible that tolerant attitudes toward immigrants are a precursor of identification with a category characterized by inclusive and universalistic values, i.e. Europe. This however does not undermine the key finding that the association between identification with Europe and anti-immigrant prejudice varies across countries as a function of normative climate defined here by immigration policies. Future research should use longitudinal designs to further explore the causality of observed associations. 
IDENTIFICATION WITH EUROPE, INTEGRATION POLICIES, AND PREJUDICE

Second, the items tapping anti-immigrant prejudice available in the data used in this study only mentioned "immigrants" with no further distinction. When answering such questions, it seems that respondents have in mind the immigrant groups that are most present where they live (Asbrock, Lemmer, Becker, Koller, \& Wagner, 2014). As some immigrants are part of the European ingroup, the identity under scrutiny here, it would be relevant in future research to distinguish views concerning immigrants coming from European countries and those coming from non-European countries.

Third, the present results cannot be generalized outside Europe. Indeed, the historicpolitical setting may be specific for current-day Europe and the inclusive nature of European identity may also be a unique feature. Research on similar mechanisms in different continents is however too scarce to attempt any comparison: While pan-ethnicity and its links to political attitudes have been studied among immigrants (e.g., pan-African or pan-Asian identities) in host countries (e.g., Okamoto \& Mora, 2014), research on the relationship between pannational identities and immigration attitudes among the national majorities in other continents has, to our knowledge, yet to be carried out. For this reason, we encourage future research to further explore this topic.

Finally, in this paper we focused on the impact of top-down, institutional norms. Integration policies were considered as embodiments of country-level norms concerning intergroup relations. Political discourse is another way to conceptualize and measure a topdown normative context (e.g., Fasel, Sarrasin, Green, \& Mayor, 2016; Helbling, Reeskens, \& Wright, 2016). In addition, the stance regarding immigration held by fellow ingroup members within a given context guide individuals' attitudes (e.g., Green \& Staerklé, 2013; van Assche, Roets, De keersmaecher, \& Van Hiel 2016). These bottom-up, shared norms can also be more or less inclusive. Top-down and bottom-up norms have a reciprocal relation: While policies shape shared attitudes by formally defining acceptable expressions regarding immigrants, 
IDENTIFICATION WITH EUROPE, INTEGRATION POLICIES, AND PREJUDICE

shared attitudes also play a part in policy making for example through influencing election of representatives aligned with the stance regarding immigration. Future studies should compare the impact of different sources of social norms on the relationship between identification with Europe and prejudice toward immigrants. Moreover, as the quotes of politicians at the outset of the paper suggest, contrasting norms can co-exist in society and individuals are exposed to them when forming their opinions regarding immigration. The impact of exposure to conflicting vs. consensual norms as well as changing norms are thus fruitful avenues for further research. In addition, as policies are often defined on the national level, the focus of the present study was on the impact of country-level normative climates only. Local-level norms, however, might also shape the relationship between identification with Europe and anti-immigrant prejudice, since they have been shown to affect covariations of individuallevels antecedents of prejudice toward cultural and migrant diversity (Fasel, Green, \& Sarrasin, 2013).

\section{Conclusion}

Europe has recently faced major demographic and social changes due to mass immigration and security threats in Europe. Our study showed that identification with Europe - despite these challenges - is associated to tolerant attitudes toward immigration, especially in countries where the European egalitarian values match the prevailing national integration policies. We hope this research triggers further investigations of the meanings associated to European identity, and pan-national identities more generally. We expect these meanings to vary across countries, which will influence the interplay between country-level normative climates and individuals' social identification in shaping intergroup attitudes. 
IDENTIFICATION WITH EUROPE, INTEGRATION POLICIES, AND PREJUDICE

\section{References}

Aguinis, H., Gottfredson, R. K., \& Culpepper, S. A. (2013). Best-practice recommendations for estimating cross-level interaction effects using multilevel modeling. Journal of Management, 39, 1490-1528.

Andreouli, E., \& Howarth, C. (2013). National identity, citizenship and immigration: Putting identity in context. Journal for the Theory of Social Behaviour, 43, 361-382.

Ariely, G. (2012). Do those who identify with their nation always dislike immigrants? An examination of citizenship policy effects. Nationalism and Ethnic Politics, 18, 242261.

Asbrock, F., Lemmer, G., Becker, J., Koller, J., \& Wagner, U. (2014). "Who are these foreigners anyway?"—The content of the term foreigner and its impact on prejudice. Sage Open, 4, 1-8.

Brewer, M. B. (2001). The many faces of social identity: Implications for political psychology. Political Psychology, 22, 115-125.

Blank, T., \& Schmidt, P. (2003). National identity in a united Germany: Nationalism or patriotism? An empirical test with representative data. Political Psychology, 24, 289312.

Callens, M. S., \& Meuleman, B. (2016). Do integration policies relate to economic and cultural threat perceptions? A comparative study in Europe. International Journal of Comparative Sociology. Advance online publication.

Campbell, D. T. (1958). Common fate, similarity, and other indices of the status of aggregates of person as social entities. Behavioural Science, 3, 14-25.

Castano, E. (2004). European identity: A social-psychological perspective. In R. K. Herrmann, T. Risse, \& M. B. Brewer (Eds.), Transnational identities: Becoming European in the EU (pp. 40-58). New York, NY: Rowman \& Littlefield. 
IDENTIFICATION WITH EUROPE, INTEGRATION POLICIES, AND PREJUDICE

Castano, E., Yzerbyt, V., \& Bourguignon, D. (2003). We are one and I like it: The impact of ingroup entitativity on ingroup identification. European Journal of Social Psychology, $33,735-754$.

Central Intelligence Agency. (2016). The world factbook. Retrieved from: https://www.cia.gov/library/publications/the-world-factbook/

Ceobanu, A. M., \& Escandell, X. (2010). Comparative analyses of public attitudes toward immigrants and immigration using multinational survey data: A review of theories and research. Annual Review of Sociology, 36, 309-328.

Chiu, C. Y., Gelfand, M. J., Harrington, J. R., Leung, A. K. Y., Liu, Z., Morris, M. W., ... \& Zou, X. (2015). A conclusion, yet an opening to enriching the normative approach of culture. Journal of Cross-Cultural Psychology, 46, 1361-1371.

Citrin, J., \& Sides, J. (2004). More than nationals: How identity choice matters in the new Europe. In R. K. Herrmann, T. Risse, \& M. B. Brewer (Eds.), Transnational identities: Becoming European in the EU (pp. 161-185). New York, NY: Rowman \& Littlefield.

Coenders, M. and Scheepers, P. (2003). The effect of education on nationalism and ethnic exclusionism: An international comparison. Political Psychology, 24, 313-343.

Crandall, C. S., Eshleman, A., \& O'Brien, L. (2002). Social norms and the expression and suppression of prejudice: The struggle for internalization. Journal of Personality and Social Psychology, 82, 359-378.

Curtis, K. A. (2014). Inclusive versus exclusive: A cross-national comparison of the effects of subnational, national, and supranational identity. European Union Politics, 15, 521546.

Datler, G. (2016). European identity as a safeguard against xenophobia? A differentiated view based on identity content. In J. Grimm, L. Huddy, P. Schmidt, \& J. Seethaler (Eds.), 
IDENTIFICATION WITH EUROPE, INTEGRATION POLICIES, AND PREJUDICE

Dynamics of National Identity: Media and Societal Factors of What We Are (pp. 229255). New York, NY: Routledge.

De Figueiredo, R. J., \& Elkins, Z. (2003). Are patriots bigots? An inquiry into the vices of ingroup pride. American Journal of Political Science, 47, 171-188.

Enders, C. K., \& Tofighi, D. (2007). Centering predictor variables in cross-sectional multilevel models: a new look at an old issue. Psychological Methods, 12, 121-138.

Falomir-Pichastor, J. M., Muñoz-Rojas, D., Invernizzi, F., \& Mugny, G. (2004). Perceived ingroup threat as a factor moderating the influence of in-group norms on discrimination against foreigners. European Journal of Social Psychology, 34, 135-153.

Fasel, N., Green, E. G. T., and Sarrasin, O. (2013). Unveiling naturalization: A multilevel study on minority proportion, conservative ideologies and attitudes towards the Muslim veil. Zeitschrift für Psychologie, 221, 242-251.

Fasel, N., Sarrasin, O., Green, E. G., \& Mayor, E. (2016). Who is to blame? Official discourse and ethnic diversity attitudes during the 2011 riots in England. Political Psychology, $37,659-675$

Gorodzeisky, A. (2011). Who are the Europeans that Europeans prefer? Economic conditions and exclusionary views toward European immigrants. International Journal of Comparative Sociology, 52, 100-113.

Green, E. G. T., \& Staerklé, C. (2013). Migration and multiculturalism. In L. Huddy, D. O. Sears, \& J. Levy (Eds.), Oxford handbook of political psychology (pp. 852-889). Oxford, UK: Oxford University Press.

Guimond, S., Crisp, R. J., De Oliveira, P., Kamiejski, R., Kteily, N., Kuepper, B., ... \& Sidanius, J. (2013). Diversity policy, social dominance, and intergroup relations: Predicting prejudice in changing social and political contexts. Journal of Personality and Social Psychology, 104, 941-958. 
IDENTIFICATION WITH EUROPE, INTEGRATION POLICIES, AND PREJUDICE

Hadler, M., Tsutsui, K., \& Chin, L. G. (2012). Conflicting and reinforcing identities in expanding Europe: Individual-and country-level factors shaping national and European identities, 1995 2003. Sociological Forum, 27, 392-418.

Helbling, M., Reeskens, T., \& Wright, M. (2016). The mobilisation of identities: A study on the relationship between elite rhetoric and public opinion on national identity in developed democracies. Nations and Nationalism, 22, 744-767.

Hjerm, M. (2001). Education, xenophobia, and nationalism: A comparative analysis. Journal of Ethnic and Migration Studies, 27, 37-60.

Hobolt, S. B., \& de Vries, C. E. (2016). Public support for European integration. Annual Review of Political Science, 19, 413-432.

Hooghe, M., \& de Vroome, T. (2015). How does the majority public react to multiculturalist policies? A comparative analysis of European countries. American Behavioral Scientist, 59, 747-768.

Hox, J. (2010). Multilevel analysis: Techniques and applications. New York, NY: Routledge. Huddleston T., Bilgili, Ö., Joki A.L. \& Vankova, Z. (2015). Migrant Integration Policy Index 2015. Brussels, Belgium: Migration Policy Group.

Kauff, M., Asbrock, F., Thörner, S., \& Wagner, U. (2013). Side effects of multiculturalism: The interaction effect of a multicultural ideology and authoritarianism on prejudice and diversity beliefs. Personality and Social Psychology Bulletin, 39, 305-320.

Kennedy, R. (2013). The role of supranational identity in promoting democratic values. European Union Politics, 14, 228-249.

Lancee, B., \& Sarrasin, O. (2015). Educated preferences or selection effects? A longitudinal analysis of the impact of educational attainment on attitudes toward immigrants. European Sociological Review, 31, 490-501. 
IDENTIFICATION WITH EUROPE, INTEGRATION POLICIES, AND PREJUDICE

Licata, L., \& Klein, O. (2002). Does European citizenship breed xenophobia? European identification as a predictor of intolerance towards immigrants. Journal of Community \& Applied Social Psychology, 12, 323-337.

Licata, L., Sanchez-Mazas, M., \& Green, E. G. (2011). Identity, immigration, and prejudice in Europe: A recognition approach. In Handbook of identity theory and research (pp. 895-916). New York, NY: Springer.

McCormick, J. (2010). Europeanism. Oxford, United Kingdom: Oxford University Press.

Morris, M. W., Hong, Y. Y., Chiu, C. Y., \& Liu, Z. (2015). Normology: Integrating insights about social norms to understand cultural dynamics. Organizational Behavior and Human Decision Processes, 129, 1-13.

Morrison, K. R., Plaut, V. C., \& Ybarra, O. (2010). Predicting whether multiculturalism positively or negatively influences White Americans' intergroup attitudes: The role of ethnic identification. Personality and Social Psychology Bulletin, 36, 1648-1661.

Mummendey, A., Klink, A., \& Brown, R. (2001). Nationalism and patriotism: National identification and out $\square$ group rejection. British Journal of Social Psychology, 40, 159172.

Okamoto, D., \& Mora, G. C. (2014). Panethnicity. Annual Review of Sociology, 40, 219-239.

Pehrson, S., Vignoles, V. L., \& Brown, R. (2009). National identification and anti-immigrant prejudice: Individual and contextual effects of national definitions. Social Psychology Quarterly, 72, 24-38.

Pettigrew, T. F. (1998). Reactions toward the new minorities of Western Europe. Annual Review of Sociology, 77-103.

Pettigrew, T. F., \& Tropp, L. R. (2011). When groups meet: The dynamics of intergroup contact. Essays in Social Psychology series. New York, NY: Psychology Press. 
IDENTIFICATION WITH EUROPE, INTEGRATION POLICIES, AND PREJUDICE

Quintelier, E., \& Dejaeghere, Y. (2008). Does European citizenship increase tolerance in young people? European Union Politics, 9, 339-362.

Reicher, S., \& Hopkins, N. (2001). Self and nation: Categorisation, contestation and mobilization. London, United Kingdom: Sage.

Sanchez-Mazas, M., Van Humskerken, F., \& Gély, R. (2005). La citoyenneté européenne et l' "Autre du dedans" [European citizenship and the « Other from the inside »]. In M.

Sanchez-Mazas \& L. Licata (Eds.), L'Autre: Regards psychosociaux. (pp. 309-336). Grenoble, France: Presses Universitaires de Grenoble.

Scheepers, P., Gijsberts, M., \& Coenders, M. (2002). Ethnic exclusionism in European countries. Public opposition to civil rights for legal migrants as a response to perceived ethnic threat. European Sociological Review, 18, 17-34.

Scheffer, J. (2002). Dealing with missing data. Research Letters in Information and Mathematical Sciences, 3, 153-160.

Schlenker, A. (2013). Cosmopolitan Europeans or partisans of Fortress Europe? Supranational identity patterns in the EU. Global Society, 27, 25-51.

Schilde, K. E. (2014). Who are the Europeans? European identity outside of European integration. JCMS: Journal of Common Market Studies, 52, 650-667.

Schlueter, E., Meuleman, B., \& Davidov, E. (2013). Immigrant integration policies and perceived group threat: A multilevel study of 27 Western and Eastern European countries. Social Science Research, 42, 670-682.

Staerklé, C. (2009). Policy attitudes, ideological values and social representations. Social and Personality Psychology Compass, 3, 1096-1112.

Strabac, Z., \& Listhaug, O. (2008). Anti-Muslim prejudice in Europe: A multilevel analysis of survey data from 30 countries. Social Science Research, 37, 268-286. 
IDENTIFICATION WITH EUROPE, INTEGRATION POLICIES, AND PREJUDICE

Skrobanek, J. (2004). Soziale Identität und Ausländerfeindlichkeit. [Social identity and xenophobia.] Berliner Journal für Soziologie, 14, 357-377.

Tajfel, H., \& Turner, J. C. (1979). An integrative theory of intergroup conflict. In W. G.

Austin \& S. Worchel (Eds.). The social psychology of intergroup relations (pp. 3347). Monterey, CA: Brooks/Cole.

United Nations, Department of Economic and Social Affairs, Population Division. (2016). International migrant stock 2015. Retrieved from:

http://www.un.org/en/development/desa/population/migration/data/estimates2/estimat es 15. shtml

Van Assche, J., Roets, A., De keersmaecker, J., \& Van Hiel, A. (2016). The mobilizing effect of right-wing ideological climates: Cross-level interaction effects on different types of outgroup attitudes. Political Psychology. Advance online publication.

Verkuyten, M. (2009). Support for multiculturalism and minority rights: The role of national identification and out-group threat. Social Justice Research, 22, 31-52.

Wagner, U., Becker, J. C., Christ, O., Pettigrew, T. F., \& Schmidt, P. (2012). A longitudinal test of the relation between German nationalism, patriotism, and outgroup derogation. European Sociological Review, 28, 319-332.

Wagner, U., Christ, O., Pettigrew, T. F., Stellmacher, J., \&Wolf, C. (2006). Prejudice and minority proportion: Contact instead of threat effects. Social Psychology Quarterly, $69,380-390$.

Weber, H. (2015). National and regional proportion of immigrants and perceived threat of immigration: A three-level analysis in Western Europe. International Journal of Comparative Sociology, 56, 116-140. 
IDENTIFICATION WITH EUROPE, INTEGRATION POLICIES, AND PREJUDICE

Weldon, S. A. (2006). The institutional context of tolerance for ethnic minorities: A comparative, multilevel analysis of Western Europe. American Journal of Political Science, 50, 331-349.

Wright, M. (2011). Diversity and the imagined community: Immigrant diversity and conceptions of national identity. Political Psychology, 32, 837-862.

Wolsko, C., Park, B., Judd, C. M., \& Wittenbrink, B. (2000). Framing interethnic ideology: Effects of multicultural and color-blind perspectives on judgments of groups and individuals. Journal of Personality and Social Psychology, 78, 635-654. 
IDENTIFICATION WITH EUROPE, INTEGRATION POLICIES, AND PREJUDICE

\section{Footnotes}

1. Regarding years of education, 52 respondents $(0.19 \%$ of the total sample) answered "still in education", and their response was treated as a missing value. Values above the mean +3.5 standard deviations (i.e., respondents who indicated 28 years of education or more, $n=$ $71,0.26 \%$ of the total sample) were also treated as missing values.

2. Regarding the transcontinental countries participating in the 2013 ISSP, we included Turkey in our sample, but not Russia and Georgia because the MIPEX index was not available for these countries. The results pattern was identical in essence when excluding Turkey from analyses.

3. The results pattern was the same when repeating analyses without replacing missing values.

4. As former East and West German data could not be distinguished, in the current data we coded Germany as a country without a socialist past. However, the results are unaltered when Germany is coded as a post-socialist country.

5. Analyses performed on EU members countries only $(N=18)$ produced a result pattern that was in essence identical to the one obtained with 22 countries.

6. When testing simultaneously the cross-level interactions between MIPEX and identification with Europe and between MIPEX and national identification (extension of Model 3b), the MIPEX $\times$ identification with Europe interaction remained significant $(b=$ $0.08, S E=0.03, p=.005)$, while the MIPEX $\times$ national identification interaction was not significant $(b=-0.02, S E=0.03, p=.456)$. 
Table 1. Number of Respondents, MIPEX, Mean Scores (and Standard Deviations), and Correlations between Identification with Europe and Anti-Immigrant Prejudice by Country

\begin{tabular}{|c|c|c|c|c|c|}
\hline Country & $N$ & MIPEX & $\begin{array}{c}M(S D) \\
\text { Identification } \\
\text { with Europe }\end{array}$ & $\begin{array}{c}M(S D) \\
\text { Anti-immigrant } \\
\text { prejudice }\end{array}$ & $\begin{array}{c}r \\
\text { Id. Europe - } \\
\text { Prejudice } \\
\end{array}$ \\
\hline Belgium & 1,908 & 70 & $2.50(0.84)$ & $56.06(21.90)$ & $-.24^{* * *}$ \\
\hline Croatia & 996 & 44 & $2.26(0.87)$ & $51.38(18.51)$ & -.01 \\
\hline Czech Republic & 1,887 & 45 & $3.02(0.80)$ & $63.67(17.98)$ & -.03 \\
\hline Denmark & 1,277 & 59 & $2.66(0.85)$ & $46.80(22.32)$ & $-.06^{*}$ \\
\hline Estonia & 870 & 49 & $2.37(0.80)$ & $52.11(17.69)$ & .00 \\
\hline Finland & 1,206 & 71 & $2.49(0.76)$ & $49.92(19.64)$ & $-.28^{* * *}$ \\
\hline France & 1,926 & 54 & $2.62(0.95)$ & $50.16(25.79)$ & $-.23^{* * *}$ \\
\hline Germany & 1,620 & 63 & $2.76(0.76)$ & $45.35(19.46)$ & $-.20^{* * *}$ \\
\hline Hungary & 1,001 & 46 & $3.19(0.77)$ & $55.91(17.55)$ & -.02 \\
\hline Iceland & 1,061 & 46 & $2.56(0.75)$ & $37.30(14.91)$ & $-.28^{* * *}$ \\
\hline Ireland & 1,105 & 51 & $2.25(0.84)$ & $43.20(19.46)$ & $-.14^{* * *}$ \\
\hline Latvia & 867 & 34 & $2.09(0.82)$ & $55.24(19.68)$ & $-.17^{* * *}$ \\
\hline Lithuania & 1,188 & 38 & $2.41(0.72)$ & $52.29(14.79)$ & .00 \\
\hline Norway & 1,445 & 69 & $2.90(0.77)$ & $47.19(18.04)$ & .00 \\
\hline Portugal & 974 & 80 & $2.68(0.84)$ & $46.95(17.81)$ & $-.33^{* * *}$ \\
\hline Slovak Republic & 1,155 & 38 & $2.68(0.77)$ & $59.02(17.25)$ & $-.08^{* *}$ \\
\hline Slovenia & 991 & 48 & $2.48(0.90)$ & $49.70(18.17)$ & $-.11^{* * *}$ \\
\hline Spain & 1,128 & 61 & $2.74(0.93)$ & $48.04(22.27)$ & -.04 \\
\hline Sweden & 1,038 & 80 & $2.55(0.82)$ & $42.20(21.41)$ & $-.16^{* * *}$ \\
\hline Switzerland & 1,019 & 46 & $2.77(0.77)$ & $45.05(16.70)$ & $-.07^{*}$ \\
\hline Turkey & 1,661 & 24 & $1.76(0.98)$ & $62.73(17.71)$ & .00 \\
\hline United Kingdom & 847 & 56 & $1.96(0.78)$ & $55.04(20.96)$ & $-.24^{* * *}$ \\
\hline
\end{tabular}

Notes. Identification with Europe ranged from 1 to 4 . Anti-immigrant prejudice ranged from 0 to 100 . ${ }^{*} p<.05 .{ }^{* *} p<.01 .{ }^{* * *} p<.001$. 
Table 2. Unstandardized Multilevel Regression Coefficients (and Standard Errors) for Individual-and Country-level Predictors of Anti-Immigrant Prejudice

\begin{tabular}{|c|c|c|c|}
\hline & Model 1 & Model 2 & Model 3b \\
\hline Intercept & $68.02(1.51)^{* * *}$ & $68.00(1.40)^{* * *}$ & $59.28(1.40)^{* * *}$ \\
\hline \multicolumn{4}{|l|}{ Individual-level predictors } \\
\hline Identification with Europe & $-3.19(0.15)^{* * *}$ & $-3.18(0.15)^{* * *}$ & $-3.12(0.43)^{* * *}$ \\
\hline National identification & $2.35(0.17)^{* * *}$ & $2.35(0.17)^{* * *}$ & $2.40(0.17)^{* * *}$ \\
\hline Gender $(1=$ male, $2=$ female $)$ & $-1.65(0.23)^{* * *}$ & $-1.65(0.23)^{* * *}$ & $-1.59(0.23)^{* * *}$ \\
\hline Age & $0.04(0.01)^{* * *}$ & $0.04(0.01)^{* * *}$ & $0.04(0.01)^{* * *}$ \\
\hline Years of Education & $-1.28(0.03)^{* * *}$ & $-1.28(0.03)^{* * *}$ & $-1.27(0.03)^{* * *}$ \\
\hline \multicolumn{4}{|l|}{ Country-level predictor } \\
\hline MIPEX & & $-0.18(0.08)^{*}$ & $-0.21(0.08)^{* *}$ \\
\hline \multicolumn{4}{|l|}{ Cross-level interaction } \\
\hline $\begin{array}{l}\text { MIPEX } \times \text { Identification } \\
\text { with Europe }\end{array}$ & & & $-0.09(0.03)^{* *}$ \\
\hline \multicolumn{4}{|l|}{ Variance components } \\
\hline Individual-level & 346.62 & & \\
\hline (\% explained variance) & $9.02 \%$ & & \\
\hline Country-level & 33.90 & 26.99 & \\
\hline (\% explained variance) & $18.14 \%$ & $34.82 \%$ & \\
\hline Random slope & & & 3.50 \\
\hline (\% explained variance) & & & $32.02 \%$ \\
\hline Deviance & $236,106.35$ & $236,101.38$ & $235,837.11$ \\
\hline
\end{tabular}

In Model 0 (intercept only model), intercept is $50.69(1.38)^{* * *}$; deviance is $238,689.98$;

individual-level variance is 381.00 ; country-level variance is 41.41 .

In Model 3a (random slope model), deviance is 235,844.72; random slope variance is 5.15 . 
IDENTIFICATION WITH EUROPE, INTEGRATION POLICIES, AND PREJUDICE

Table 3. Unstandardized Multilevel Regression Coefficients (and Standard Errors) for Country-level Predictors of Anti-Immigrant Prejudice

\begin{tabular}{|c|c|c|c|c|c|}
\hline & $\begin{array}{c}\text { Model 3c } \\
\% \text { immigrants }\end{array}$ & $\begin{array}{c}\text { Model 3d } \\
\text { \% unemployment }\end{array}$ & $\begin{array}{l}\text { Model 3e } \\
\text { GINI index }\end{array}$ & $\begin{array}{c}\text { Model 3f } \\
\text { Post-socialist } \\
\text { country }\end{array}$ & $\begin{array}{l}\text { Model } 3 g \\
\text { EU affiliation }\end{array}$ \\
\hline \multicolumn{6}{|l|}{ Country-level predictors } \\
\hline MIPEX & $-0.17(0.07)^{*}$ & $-0.21(0.08)^{* *}$ & $-0.23(0.08)^{* *}$ & $-0.12(0.08)$ & $-0.25(0.07)^{* * *}$ \\
\hline Predictor 2 & $-0.42(0.17)^{*}$ & $0.00(0.24)$ & $-0.18(0.26)$ & $-2.54(1.24)^{*}$ & $2.98(1.30)^{*}$ \\
\hline \multicolumn{6}{|l|}{ Cross-level interactions } \\
\hline MIPEX $\times$ Identification with Europe & $-0.09(0.03)^{* *}$ & $-0.09(0.03)^{* *}$ & $-0.08(0.03)^{*}$ & $-0.06(0.03)^{\dagger}$ & $-0.08(0.03)^{* *}$ \\
\hline $\begin{array}{l}\text { Predictor } 2 \times \text { Identification with } \\
\text { Europe }\end{array}$ & $0.00(0.08)$ & $0.08(0.09)$ & $0.08(0.10)$ & $-0.78(0.50)$ & $-0.47(0.56)$ \\
\hline$\Delta$ Deviance $(\Delta \mathrm{df})^{\mathrm{a}}$ & $5.31(2)^{\dagger}$ & $0.86(2)$ & $1.01(2)$ & $6.12(2)^{*}$ & $5.41(2)^{\dagger}$ \\
\hline
\end{tabular}

Notes. Country-level controls were added to Model $3 \mathrm{~b}$ one by one as predictors of prejudice and of the variation between identification with Europe and prejudice. Post-socialist countries were coded -1 , while non-post-socialist countries were coded +1 (Model 3f). Non-EU members were coded -1 , while EU members were coded +1 (Model 3g). ${ }^{\dagger} p \leq .07 .{ }^{*} p<.05 .{ }^{* *} p<.01 .{ }^{* * *} p<.001 .{ }^{\text {a }}$ Deviance change was calculated compared to Model $3 b$. 
Figure 1. Anti-Immigrant Prejudice as a Function of Identification with Europe and CountryLevel MIPEX.

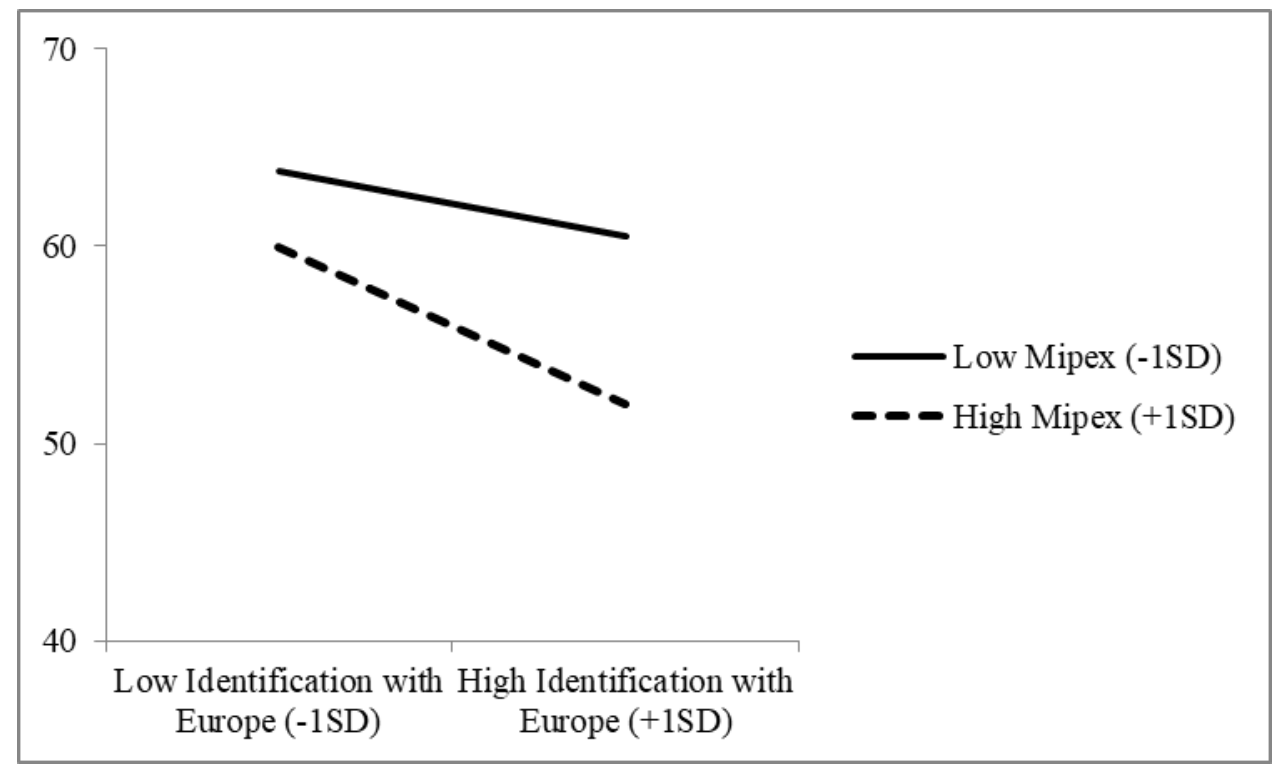

